\title{
Growth, Yield and Nutritional Performance of Sweet Sorghum and Legumes in Sole and Intercropping Influenced by Type of Legume, Nitrogen Level and Air Quality
}

\author{
Muhammad Arshad ${ }^{1 *}$, Rab Nawaz ${ }^{2}$, Sajjad Ahmad ${ }^{3}$, Ghulam Abbas Shah ${ }^{4}$, \\ Furrukh Faiz', Naveed Ahmad ${ }^{3}$, Muhammad Atif Irshad ${ }^{2}$, \\ S.L. Ranamukhaarachchi ${ }^{5}$ \\ ${ }^{1}$ Department of Agriculture \& Food Technology, Karakoram International University, Gilgit-Baltistan, Pakistan \\ ${ }^{2}$ Department of Environmental Sciences, The University of Lahore, Lahore, Pakistan \\ ${ }^{3}$ Department of Environmental Sciences, COMSATS University Islamabad, Vehari Campus, Pakistan \\ ${ }^{4}$ Department of Agronomy, PMAS-Arid Agriculture University Murree Road Rawalpindi, Pakistan \\ ${ }^{5}$ Agriculture Systems and Engineering, School of Environment, Resources and Development, \\ Asian Institute of Technology, Pathumthani, Thailand
}

Received: 15 December 2018

Accepted: 17 February 2019

\begin{abstract}
Sweet sorghum is a drought-tolerant cereal widely grown as pure stand in water-scarce areas. In the context of ongoing climate change, some agronomic adjustments are required for sustainable food production. Intercropping sweet sorghum with mungbean and soybean was assessed under three $\mathrm{N}$ levels $\left(30,60,120 \mathrm{~kg} \mathrm{ha}^{-1}\right)$ and two types of air quality environments (charcoal filtered air and ambient air). Grain yield of sweet sorghum was significantly $(\mathrm{P} \leq 0.001)$ reduced in intercropping with mungbean (4.5 $\left.\mathrm{t} \mathrm{ha}^{-1}\right)$, but remained on par $(\mathrm{P}>0.05)$ between sole cropping $\left(5.1 \mathrm{t} \mathrm{ha}^{-1}\right)$ and intercropping with soybean $\left(5.1 \mathrm{t} \mathrm{ha}^{-1}\right)$. Nitrogen application at $60 \mathrm{~kg} \mathrm{ha}^{-1}$ optimized the grain yield, LER (1.8-1.9) and nutritional outputs of carbohydrate, protein, fat, and energy in intercropping (4.7 t, $1.0 \mathrm{t}, 0.2 \mathrm{t}$, and 102.5 $\mathrm{MJ} \mathrm{ha}^{-1}$, respectively) compared to that in sole cropping of sweet sorghum $(3.6 \mathrm{t}, 0.5 \mathrm{t}, 0.1 \mathrm{t}$, and 74.6 $\mathrm{MJ} \mathrm{ha}^{-1}$, respectively). Charcoal-filtered air with reduced air pollutants of $\mathrm{O}_{3}, \mathrm{NO}_{2}$ and $\mathrm{SO}_{2}$ significantly $(\mathrm{P} \leq 0.05)$ improved the growth and seed yield of intercropped mungbean $\left(2.1\right.$ tha $\left.^{-1}\right)$ and soybean $\left(1.8\right.$ tha $\left.^{-1}\right)$, and overall land productivity compared to ambient air (1.7 and $1.2 \mathrm{t} \mathrm{ha}^{-1}$, respectively).
\end{abstract}

Keywords: air pollutants, energy, food ingredients, intercropping, nitrogen

*e-mail: dr.arshad@kiu.edu.pk, arshad4humanity@yahoo.com 


\section{Introduction}

Intercropping is widely practiced to sustain food production in resource-poor rural farming to ensure food security. Many environmental issues,i.e., water scarcity, air and water pollution, over-fertilization, high nitrous emissions, leaching and ongoing climate change, affect food production systems and reducing crop yields and food availability. Sole cropping threatens the income security and nutritional diversity in rural areas due to adverse effects of climate change associated with unexpected pest and disease outbreaks. Intercropping provides alternatives and multiple advantages with increasing efficiencies of land use [1], solar radiation [2], irrigation water [3], and nitrogen [4]. Cereals combined with legumes in intercropping increases total productivity per unit area and improves quality of output $[5,6]$.

Sorghum is grown worldwide as a multipurpose crop [7]. It can tolerate adverse climatic conditions like drought [8] and temperature fluctuations $[9,10]$ and can grow on marginal soils $[11,12]$. The crop is capable of overcoming adverse climatic conditions through flexible growth patterns and sustains grain and biomass production levels [13]. However, in intercropping, the type of legume and nitrogen management influence its growth and yield [14]. Although adverse effects of ambient air have been reported on the crop [15], it was also categorized as a somewhat resistant plant to most of the air pollutants [16]. Balanced use of fertilizer helps improve grain yield and maintains its nutritive value in intercropping in order to meet increased land productivity targets [17].

Nitrogen management in cropping systems has significance for optimizing production cost and reducing the contribution to air pollution. Under-fertilization reduces food production while over-fertilization leads to environmental problems like air pollution [18]. Augmenting air pollution [19], increased use of nitrogen for crop production [20] and enhanced demands for energy detrimentally influence growth and yield of crops [21] and food quality deterioration [22]. Air pollutants that have direct influence on plants include $\mathrm{O}_{3}$, $\mathrm{NO}_{2}$ and $\mathrm{SO}_{2}$, which cause visible and invisible damage at higher concentrations [23]. The threshold levels of $\mathrm{O}_{3}$, $\mathrm{NO}_{2}$ and $\mathrm{SO}_{2}$ usually considered for vegetation are 40 , 53 and $500 \mathrm{ppb}$, respectively, for individual influence, but the synergistic effect of air pollutants also has been reported [24].

Productivity of intercropping compared to sole cropping with emphasis on grain production has been widely reported. However, the potential and feasibility of sweet sorghum with ability of stress tolerance in intercropping has not been reported. Furthermore, mungbean and soybean as a companion of sweet sorghum in intercropping under the scenario of changing $\mathrm{N}$ levels and air quality also have not been addressed. The aim of this research work was to record observations and compare growth and yield performance of sweet sorghum and selected legumes grown under sole and intercropping systems with various agronomic practices and air quality management.

\section{Material and Methods}

\section{Study site}

A research experiment was conducted at the field research farm of agricultural systems and engineering field of study in the Asian Institute of Technology, Pathumthani, Thailand during a dry period of 2012.

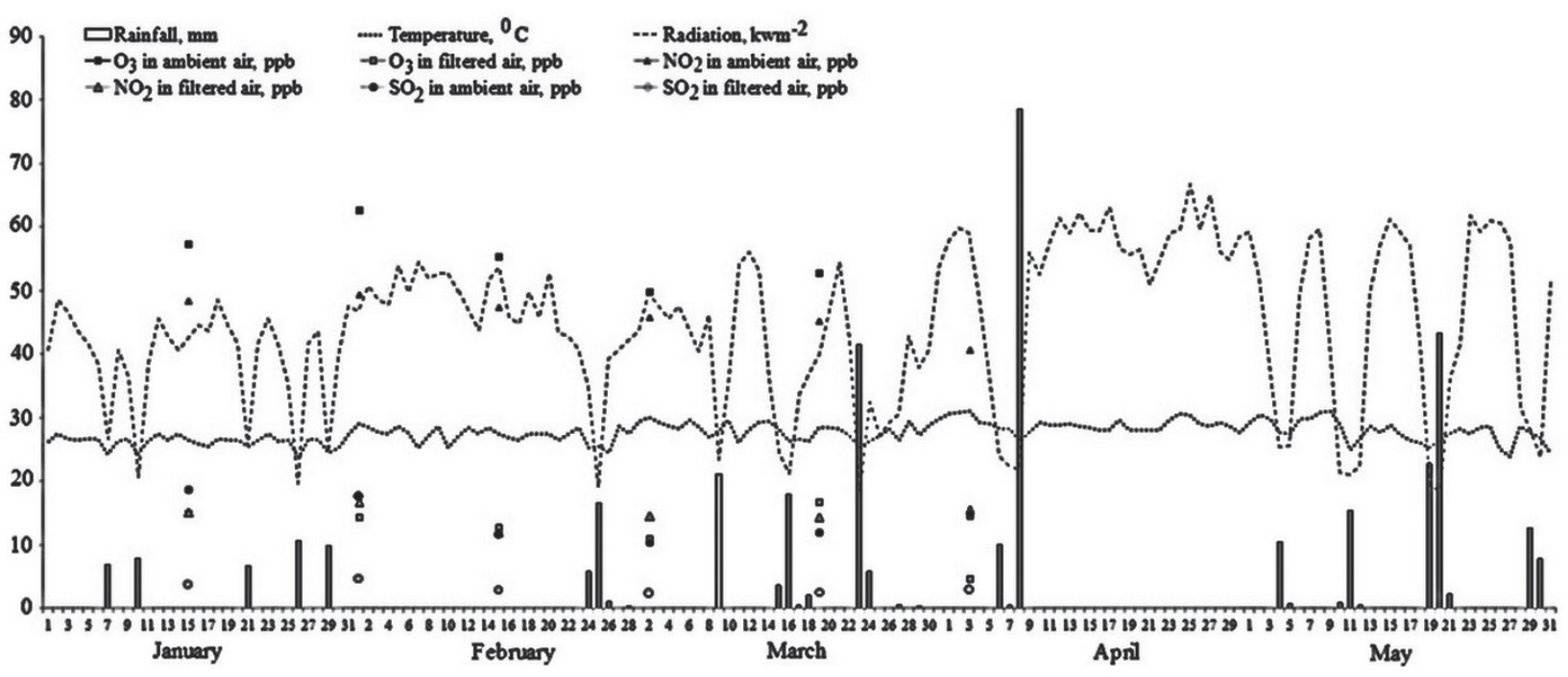

Fig. 1. Daily rainfall, temperature and solar radiation from January to May of 2012, and concentrations of ozone $\left(\mathrm{O}_{3}\right)$, nitrogen dioxide $\left(\mathrm{NO}_{2}\right)$ and sulfur dioxide $\left(\mathrm{SO}_{2}\right)$ in ambient and filtered air at 2, 4, 6, 8, 10, and 12 weeks after seeding. 
Fig. 1 shows that most of the days during the experiment were dry and temperature ranges around $24-27^{\circ} \mathrm{C}$ in January, $25-29^{\circ} \mathrm{C}$ in February, $25-30^{\circ} \mathrm{C}$ in March, $26-31^{\circ} \mathrm{C}$ in April, and heavily fluctuated between $24-31^{\circ} \mathrm{C}$ in May. Accumulated solar radiation was 1,223.0, 1,297.0, 1,236.3, 1,614.8, and 1,350.7 $\mathrm{KWm}^{-2}$ during January, February, March, April, and May, respectively. These conditions have been recognized for promoting air pollutants such as $\mathrm{O}_{3}, \mathrm{NO}_{2}$ and $\mathrm{SO}_{2}$, and hence affect crop growth.

\section{Experiment Design and Layout}

The land was previously under fallow and occupied by grasses. Twelve factorial combinations composed of two intercropping patterns (viz. sweet sorghum and mungbean or soybean), three $\mathrm{N}$ doses (viz. 30, 60, $120 \mathrm{~kg} \mathrm{ha}^{-1}$ ) and two air quality levels [viz. charcoal filtered air and unfiltered (ambient) air], and three sole crops of sweet sorghum, mungbean and soybean in a completely randomized design tested together with three replications. Recommended varieties of sweet sorghum (KKU-40), mungbean (Chinat-72 - determinate type) and soybean (Nakhorn Swan-1 - indeterminate type) for Thailand were used for this study. Land was prepared using a disc harrow and a rotary tiller and a plank, and plots were prepared as raised beds. Plot size was $4 \times 6 \mathrm{~m}$ while $1.5 \mathrm{~m}$ space was maintained between the plots. All crops were seeded simultaneously on 2 January 2012. Crop rows were oriented east-west. Sole crops of sweet sorghum, mungbean and soybean were seeded in $45 \mathrm{~cm}$ rows and with intra row spacing of 15,10 and $20 \mathrm{~cm}$, respectively. In intercropping, sweet sorghum was seeded at $45 \mathrm{~cm}$ and the legume in the middle of two sweet sorghum rows. The plant densities of sweet sorghum $\left(148,148\right.$ plants $\left.\mathrm{ha}^{-1}\right)$, mungbean $\left(222,222\right.$ plants $\left.\mathrm{ha}^{-1}\right)$ and soybean $\left(111,111\right.$ plants $\left.\mathrm{ha}^{-1}\right)$ were maintained the same in both intercropping and sole crops.

\section{Experimental Management}

The corresponding intercropping plots were provided with three rates of $\mathrm{N}$ as 30,60 and $120 \mathrm{~kg} \mathrm{ha}^{-1}$ as per treatment. Sole cropped sweet sorghum was given $60 \mathrm{~kg} \mathrm{~N}, 20 \mathrm{~kg} \mathrm{P}$ and $20 \mathrm{~kg} \mathrm{~K} \mathrm{ha}{ }^{-1}$ and total $\mathrm{P}$ and $\mathrm{K}$ were applied at sowing. The dose of $\mathrm{N}$ was divided into two splits and $50 \%$ applied at sowing and the remainder at booting stage for sole crop of sweet sorghum. For both sole crops of mungbean and soybean, $\mathrm{N}$ and $\mathrm{P}$ were applied at the rate of 30 and $20 \mathrm{~kg} \mathrm{ha}^{-1}$, respectively, at seeding. Eighteen open top chambers with 2-m diameter and $2-\mathrm{m}$ height were built in randomly selected plots using bamboo, iron rods and thin plastic sheets for filtered air supply. Two improvised carbon filters were connected to each chamber using thick-walled plastic tubes with a uniform length in order to maintain even distribution of filtered air among chambers. The air was filtered using ground charcoal, for which filters were improvised using a $60 \mathrm{~cm}$ long pvc pipe and locally available ground charcoal. The filtered air was continuously supplied from 9.00 am to $4.00 \mathrm{pm}$ throughout the study period with an air pump (PUMA, model: XM-2525) having output of $200 \mathrm{Lmin}^{-1}$ (3 hp, $10 \mathrm{~kg}$ per psi) in order to remove air pollutants $\left(\mathrm{O}_{3}, \mathrm{NO}_{2}\right.$ and $\mathrm{SO}_{2}$ ) from chambers.

\section{Sampling and Measurements}

Air sampling was adopted from 9.00 a.m. to noon and from 1.00 to 4.00 p.m. commencing from two weeks after seeding and continued fortnightly until 12 weeks. Sampling units were prepared using four $100 \mathrm{~mL}$ plastic bottles, a small air pump (BOYU, model: SC-3500) with output of $2.5 \mathrm{~L} \mathrm{~min}^{-1}(0.012 \mathrm{MPa})$ and plastic tubing. A separate power line was set up for every plot with a single switch to control time duration of air sampling uniform. The plastic bottles contained the specific absorbent solutions as per pollutant expected (i.e., $\mathrm{O}_{3}$, $\mathrm{NO}_{2}$ and $\mathrm{SO}_{2}$ analysis) together with control (distilled water). Following the absorption, solutions were transferred to a laboratory and stored in a refrigerator at $0^{\circ} \mathrm{C}$. Respective solutions were used for analysis of $\mathrm{O}_{3}$, $\mathrm{NO}_{2}$ and $\mathrm{SO}_{2}$ as per methods described by Michel and Seidling [25] for ozone and EPA [26] for sulfur dioxide and nitrogen dioxide.

Both sweet sorghum and legume plants were sampled for growth and yield-related observations. For leaf area estimation, five consecutive plants each from sweet sorghum and legume were randomly selected from a row and harvested at flowering stage of each crop in both sole and intercropping. In the case of sweet sorghum, the length and width of each leaf were measured for every sampled plant and recorded. The leaf area was calculated following the method described by Weiss et al. [27]. In the case of legumes, leaf area was estimated using the disc method as illustrated by Garnier et al. [28]. Finally, leaf area was divided by land area subtending the plants to obtain leaf area index. Plant height of sweet sorghum and legumes was measured from plants removed from 2-m length rows at physiological maturity of each crop after leaving a border area from either end. Plant height was recorded from the ground level up to the uppermost point of the plant. Plant biomass and grains/seeds of sweet sorghum and legumes were separated and weights were recorded after drying the plant parts at $80^{\circ} \mathrm{C}$ in an oven until a constant weight was reached. Grain moisture content was determined on dry weight basis and was finally converted to moisture content at $16 \%$ for sweet sorghum and $10 \%$ for both mungbean and soybean.

The land equivalent ratio (LER) was computed following the method described by Morales-Rosales and Franco-Mora [29]. The total carbohydrates, protein, fat, and energy outputs resulted from sweet sorghum, mungbean and soybean in intercropping and sole cropping were calculated using published 
information and at moisture contents in grains/seeds of sweet sorghum, mungbean and soybean of 12.0, 9.0 and $9.5 \%$, respectively. The carbohydrates contents in corresponding crops were 70.7, 62.6 and $30.2 \mathrm{~g}$, respectively, protein contents 10.4, 23.9 and 36.5 $\mathrm{g}$, respectively, and fat contents $3.1,1.2$ and $19.9 \mathrm{~g}$, respectively, per $100 \mathrm{~g}$ seeds [30]. The digestible energy contents in carbohydrate, protein and fat were 17, 16 and $37 \mathrm{~kJ} \mathrm{~g}^{-1}$ (or 4, 4, $9 \mathrm{kcal} \mathrm{g}^{-1}$ ) of dry weight, respectively [31]. Total energy output of sole crop of sweet sorghum and intercropping system was also calculated, taking into consideration the total outputs of carbohydrate, protein and fat.

Orthogonal contrast procedure was adopted to compare the performance of crops in sole and intercropping stands [32]. The analysis of variance was performed for normal data to determine the treatment effects [33] and Fisher's protected least significant difference (LSD) procedure to compare the significance of means and their interactions [34].

\section{Results}

Concentrations of ozone $\left(\mathrm{O}_{3}\right)$, nitrogen dioxide $\left(\mathrm{NO}_{2}\right)$ and sulfur dioxide $\left(\mathrm{SO}_{2}\right)$ in ambient air (outside the chambers) were very high and significantly low in chambers due to filtration adopted during circulation at all sampling stages (Table 1). There was a slight reduction in all the gases in the research plots, and the chambers over time. In sweet sorghum, plant height was significantly $(\mathrm{P} \leq 0.001)$ reduced in intercropping with mungbean $(2.3 \mathrm{~m})$, but remained at par $(\mathrm{P}>0.05)$ when intercropped with soybean $(2.6 \mathrm{~m})$ compared to the sole crop $(2.5 \mathrm{~m})$.

\section{Growth Performance}

There was a significant interaction between the type of legume and $\mathrm{N}$ dose on plant height in intercropping ( $\mathrm{P} \leq 0.05$, Fig. 2a). Plant height of sweet sorghum was greater with soybean $(2.6-2.7 \mathrm{~m})$ than mungbean (2.0-2.4 $\mathrm{m})$ and the sole crop $(2.5 \mathrm{~m})$ at all doses of $\mathrm{N}$. With mungbean, plant height increased with increasing $\mathrm{N}$ dose, but the resultant height was not on par with that of its sole crop at any $\mathrm{N}$ dose.

There was a reduction in plant height of intercropped legumes compared to sole cropping, which accounted for about $0.37 \mathrm{~m}$ for mungbean and $0.46 \mathrm{~m}$ in case of soybean compared to the respective sole crops. There was a significant interaction between $\mathrm{N}$ dose and air quality $(\mathrm{P} \leq 0.001)$ for the plant height of intercropped mungbean and soybean (Fig. 2d \& g). In mungbean, plants were taller with filtered air than with ambient air receiving $\mathrm{N}$ levels of 30 and $60 \mathrm{~kg} \mathrm{ha}^{-1}$, but the difference was not significant $(\mathrm{P}>0.05)$ between the two $\mathrm{N}$ levels. In soybean, filtered air at $30 \mathrm{~kg} \mathrm{ha}^{-1} \mathrm{~N}$ had significantly $(\mathrm{P} \leq 0.05)$ greater plant height compared to the rest. However, filtered air together with either 30 or $60 \mathrm{~kg} \mathrm{ha}^{-1}$ of $\mathrm{N}$ produced the highest plant height of intercropped mungbean $(1.2 \mathrm{~m})$, and it was almost at par with its sole crop. But none of the combination of

Table 1. Concentrations of ozone $\left(\mathrm{O}_{3}\right)$, nitrogen dioxide $\left(\mathrm{NO}_{2}\right)$ and sulfur dioxide $\left(\mathrm{SO}_{2}\right)$ at different growth stages.

\begin{tabular}{|c|c|c|c|c|c|c|}
\hline Air Quality & $2-\mathrm{WAS}^{\prime 1}$ & 4-WAS & 6-WAS & 8-WAS & 10-WAS & 12-WAS \\
\hline \multicolumn{7}{|c|}{$\mathrm{O}_{3}$} \\
\hline Filtered & $15.1 \pm 1.5^{\mathrm{b} 2 /}$ & $14.4 \pm 3.9^{b}$ & $12.8 \pm 2.6^{b}$ & $11.1 \pm 2.1^{\mathrm{b}}$ & $16.7 \pm 3.3^{\mathrm{b}}$ & $14.5 \pm 2.9^{b}$ \\
\hline Ambient & $57.4 \pm 6.4^{\mathrm{a}}$ & $62.6 \pm 2.1^{\mathrm{a}}$ & $55.4 \pm 5.1^{\mathrm{a}}$ & $49.8 \pm 7.8^{\mathrm{a}}$ & $52.7 \pm 9.9^{a}$ & $44.6 \pm 3.9^{\mathrm{a}}$ \\
\hline $\operatorname{LSD}(\mathrm{P}=0.05)$ & 3.5 & 2.4 & 3.1 & 4.9 & 5.6 & 2.5 \\
\hline $\mathrm{CV}, \%$ & 14.0 & 9.0 & 13.2 & 23.4 & 23.3 & 12.5 \\
\hline \multicolumn{7}{|c|}{$\mathrm{NO}_{2}$} \\
\hline Filtered & $15.1 \pm 05.7^{\mathrm{b}}$ & $16.7 \pm 04.5^{\mathrm{b}}$ & $12.1 \pm 04.9^{b}$ & $14.5 \pm 03.5^{b}$ & $14.3 \pm 06.5^{\mathrm{b}}$ & $15.6 \pm 09.5^{\mathrm{b}}$ \\
\hline Ambient & $48.4 \pm 17.2^{\mathrm{a}}$ & $49.5 \pm 13.5^{\mathrm{a}}$ & $47.4 \pm 13.5^{\mathrm{a}}$ & $45.8 \pm 14.3^{\mathrm{a}}$ & $45.2 \pm 19.5^{\mathrm{a}}$ & $40.7 \pm 13.0^{\mathrm{a}}$ \\
\hline $\operatorname{LSD}(\mathrm{P}=0.05)$ & 9.8 & 7.6 & 7.8 & 7.8 & 10.7 & 8.1 \\
\hline $\mathrm{CV}, \%$ & 44.7 & 33.3 & 38.0 & 37.4 & 52.4 & 42.0 \\
\hline \multicolumn{7}{|c|}{$\mathrm{SO}_{2}$} \\
\hline Filtered & $03.9 \pm 1.0^{\mathrm{b}}$ & $04.8 \pm 1.0^{\mathrm{b}}$ & $02.9 \pm 0.9^{b}$ & $02.4 \pm 0.9^{b}$ & $02.5 \pm 0.3^{\mathrm{b}}$ & $03.0 \pm 0.5^{\mathrm{b}}$ \\
\hline Ambient & $18.8 \pm 6.3^{\mathrm{a}}$ & $17.6 \pm 5.3^{\mathrm{a}}$ & $11.7 \pm 3.8^{\mathrm{a}}$ & $10.5 \pm 2.4^{\mathrm{a}}$ & $12.0 \pm 6.5^{\mathrm{a}}$ & $14.9 \pm 4.5^{\mathrm{a}}$ \\
\hline $\operatorname{LSD}(\mathrm{P}=0.05)$ & 3.3 & 2.7 & 2.0 & 1.3 & 3.5 & 2.4 \\
\hline $\mathrm{CV}, \%$ & 42.7 & 35.6 & 38.9 & 28.6 & 69.7 & 39.6 \\
\hline
\end{tabular}

1/ WAS_weeks after sowing

$2 /$ different alphabets on means of same parameter indicates significant difference and vice versa. 
$\mathrm{N}$ dose and air quality behaved in the same manner in soybean.

Leaf area index (LAI) of sweet sorghum was the highest in its sole crop (6.6) compared to intercropping, which ranged from 5.9 with mungbean to 6.5 with soybean. The reduction in LAI in intercropping was significant $(\mathrm{P} \leq 0.001)$ where inter cropped with mungbean. Where inter cropped with soybean, LAI of sweet sorghum was not significantly $(\mathrm{P}>0.05)$ reduced. Among the three factors, the type of intercrop and $\mathrm{N}$ dose had a significant $(\mathrm{P} \leq 0.05)$ interaction on LAI (Fig. 2b), and results showed that increasing the $\mathrm{N}$ dose from 30 to $60 \mathrm{~kg} \mathrm{ha}^{-1}$ increased the LAI of sweet sorghum significantly with no further significant increase at $120 \mathrm{~kg} \mathrm{ha}^{-1}$. The LAI of sweet sorghum intercropped with mungbean significantly increased with increasing $\mathrm{N}$ dose from 30 (5.1) to $60 \mathrm{~kg} \mathrm{ha}^{-1}$ (6.2) and the increase was even greater than in sweet sorghum intercropped with soybean at the same doses of $\mathrm{N}$. But sweet sorghum intercropped with soybean and receiving $60 \mathrm{~kg} \mathrm{ha}^{-1}$ of $\mathrm{N}$ produced the highest LAI (6.6) and was on par with the sole crop.The LAI of mungbean was decreased significantly in intercropping (3.3) compared to sole cropping (4.3). However, in soybean the LAI increased in intercropping (4.3) compared to the sole crop (3.8). There was a significant $(\mathrm{P} \leq 0.05)$ interaction between $\mathrm{N}$ dose and air quality for the LAI of intercropped legumes. The highest LAI of mungbean was in the filtered air combined with $30 \mathrm{~kg} \mathrm{ha}^{-1}$ of $\mathrm{N}$ (4.2) and insignificantly decreased with increasing $\mathrm{N}$ dose up to $60 \mathrm{~kg} \mathrm{ha}^{-1}(1.0$, Fig 2e and h). The lowest LAI of 1.2 was at $120 \mathrm{~kg} \mathrm{ha}^{-1}$ and unfiltered air combination. In soybean, LAI in filtered air at all doses of $\mathrm{N}$ was greater than its sole crop. Similar to mungbean, LAI of soybean was also the highest in the filtered air and $30 \mathrm{~kg} \mathrm{ha}^{-1} \mathrm{~N}$ (5.0) combination, and gradually decreased

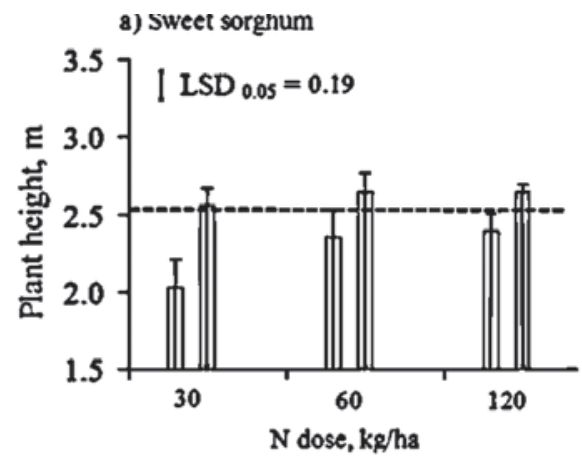

b) Sweet sorghum

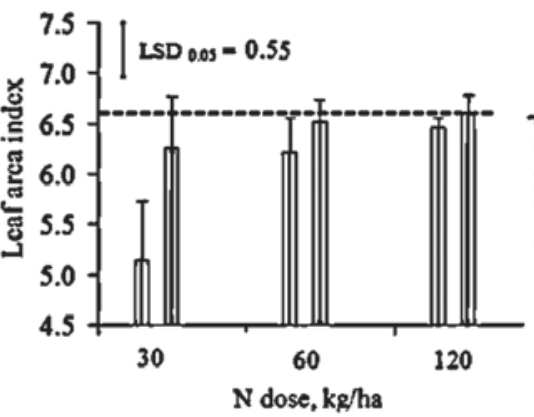

e) Mung bean
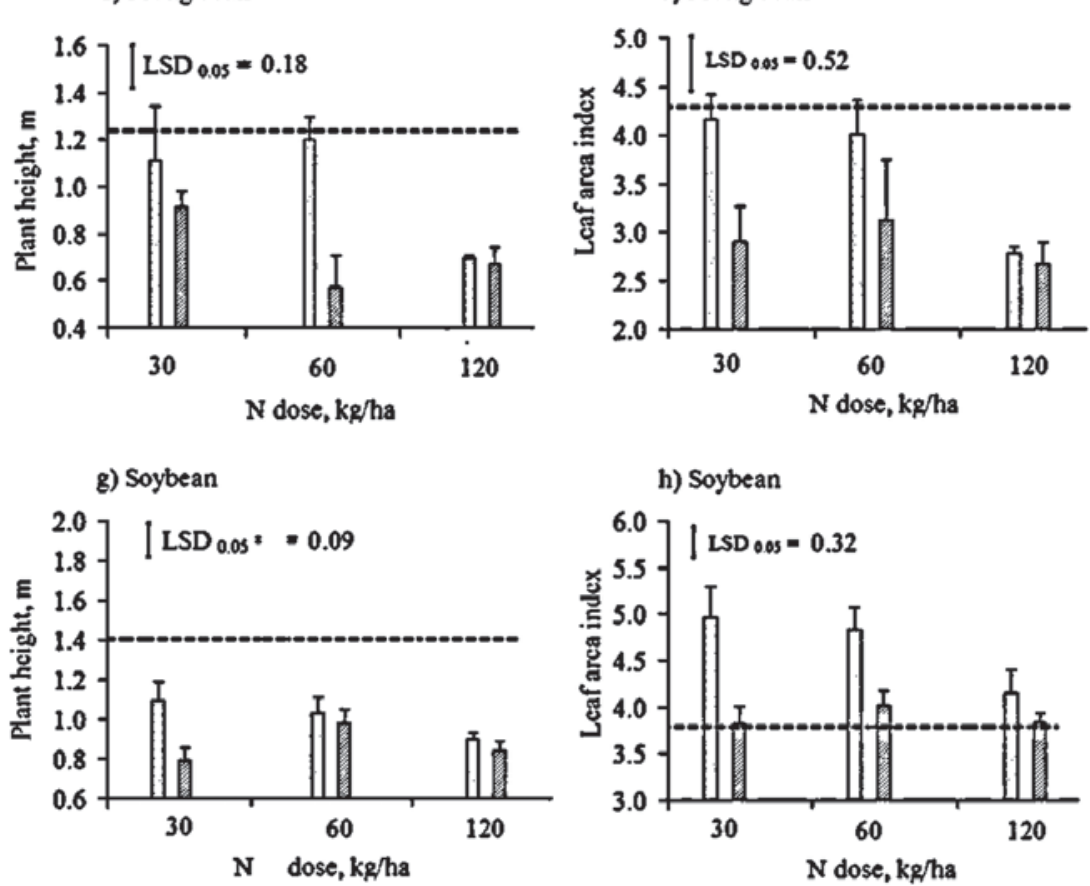

h) Soybean
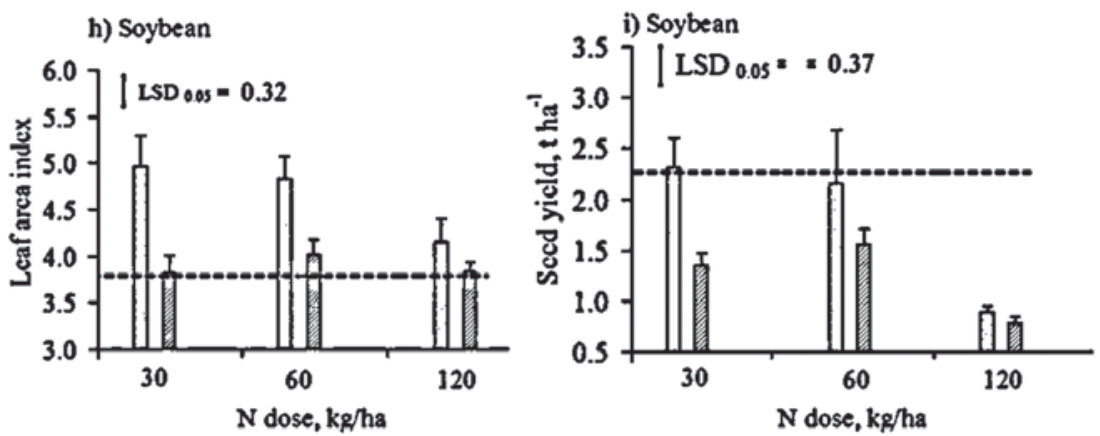

m Mung bean m Soybean a Filtered air a Ambient air -- Sole crop

Fig. 2. The effect of two-way interactions: between type of legume and $\mathrm{N}$ dose on plant height a), LAI b) and grain yield c) of sweet sorghum and between $\mathrm{N}$ dose and air quality on plant height $\mathrm{d}$ and $\mathrm{g}$ ), LAI e and $\mathrm{h}$ ) and seed yield $\mathrm{f}$ and i) of mungbean and soybean (performance of respective parameters in corresponding sole crops is shown by horizontal line). 
with increasing $\mathrm{N}$ up to $120 \mathrm{~kg} \mathrm{ha}^{-1}$ (2.8).

\section{Yield Performance}

Grain yield of sweet sorghum intercropped with soybean $\left(5.2 \mathrm{t} \mathrm{ha}^{-1}\right)$ was on par with its sole crop $\left(5.1 \mathrm{t} \mathrm{ha}^{-1}\right)$, but was significantly $(\mathrm{P} \leq 0.001)$ greater than with mungbean $\left(4.5 \mathrm{t} \mathrm{ha}^{-1}\right)$. Furthermore, the yield of sweet sorghum was significantly $(\mathrm{P} \leq 0.05)$ influenced by the interaction between the type of legume and $\mathrm{N}$ dose. The yield was greater at all three $\mathrm{N}$ levels when sweet sorghum was intercropped with soybean (4.8-5.5 $\mathrm{t} \mathrm{ha}^{-1}$ ) than with mungbean (4.3-4.7 $\mathrm{t} \mathrm{ha}^{-1}$, Fig 2c). In the presence of intercropped soybean, grain yield of sweet sorghum increased significantly with increasing $\mathrm{N}$ from 30 to $120 \mathrm{~kg} \mathrm{ha}^{-1}$, and also from 60 to $120 \mathrm{~kg} \mathrm{ha}^{-1}$, while these yields were even greater than sole crop. On the other hand, grain yield was lower with mungbean than soybean as well as its sole crop than the sweet sorghum and soybean pattern.

Seed yield of legumes was significantly $(\mathrm{P} \leq 0.05)$ decreased in intercropping (1.9 and $1.5 \mathrm{~kg} \mathrm{ha}^{-1}$ ) compared to sole cropping (2.3 and $2.3 \mathrm{t} \mathrm{ha}^{-1}$ ) of mungbean and soybean, respectively. There was a significant interaction between $\mathrm{N}$ dose and air quality for seed yield of legumes in intercropping. Under filtered air, intercropped mungbean gave significantly greater yield than ambient air, but the difference remained insignificant within all three $\mathrm{N}$ rates (Fig. $2 \mathrm{f}$ and i). Seed yield of mungbean decreased significantly $(\mathrm{P} \leq 0.05)$ with increasing $\mathrm{N}$ level beyond $60 \mathrm{~kg} \mathrm{ha}^{-1}$. Intercropped soybean behaved similar to mungbean, but the seed yield was very much reduced under ambient air, and was below $1.0 \mathrm{t} \mathrm{ha}^{-1}$ at $120 \mathrm{~kg} \mathrm{ha}^{-1} \mathrm{~N}$. The plants exposed to ambient air showed a yield increase with increasing $\mathrm{N}$ from 30 to $60 \mathrm{~kg} \mathrm{ha}^{-1}$, but decreased beyond $60 \mathrm{~kg} \mathrm{ha}^{-1}$.

\section{Land Equivalent Ratio}

Land equivalent ratio (LER) of intercrops was significantly influenced by $\mathrm{N}$ dose and air quality but not by the type of legumes. Within legumes, LER was greater at $60 \mathrm{~kg} \mathrm{ha}^{-1}$ of $\mathrm{N}$ and in filtered air (1.9), and both values were lower in soybean (Table 2). All the intercropping treatments had LER above 1.0, indicating yield advantages of intercropping over sole cropping.

\section{Nutritional Performance}

Outputs of carbohydrate, protein, fat, and energy in sole crop of sweet sorghum were 3.6, 0.5, and $0.16 \mathrm{t}$, and $74.6 \mathrm{MJ} \mathrm{ha}^{-1}$ and were significantly $(\mathrm{p} \leq 0.001)$ increased in intercropping, except for the fat in sweet sorghum-mungbean intercropping $(\mathrm{P}>0.05)$. Within intercropping, the type of legume, $\mathrm{N}$ dose and air quality had a significant effect on outputs of carbohydrate, fat and digestible energy (Table 3). Outputs of these parameters were significantly $(\mathrm{P} \leq 0.05)$ higher in sweet sorghum-soybean intercropping compared to sweet

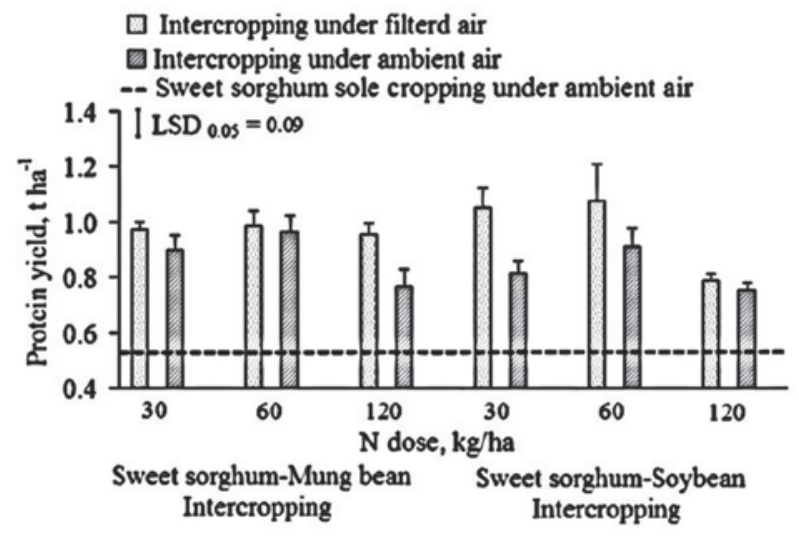

Fig. 3. Effect of three-way interaction among type of legumes, $\mathrm{N}$ dose and air quality on total protein output of intercropping (horizontal line shows protein output of sole cropped sweet sorghum).

sorghum-mungbean intercropping, and at $\mathrm{N}$ dose of $60 \mathrm{~kg} \mathrm{ha}^{-1}$ than 30 and $120 \mathrm{~kg} \mathrm{ha}^{-1}$ and in filtered air than ambient air. There was a significant $(\mathrm{P} \leq 0.01)$ three-way interaction among the type of legume, $\mathrm{N}$ dose and air quality for the output of protein in intercropping (Fig. 3). The highest output of protein $\left(1.08 \mathrm{t} \mathrm{ha}^{-1}\right)$ was in sweet sorghum-soybean intercropping receiving $60 \mathrm{~kg} \mathrm{ha}^{-1}$ of $\mathrm{N}$ and exposed to filtered air. Furthermore, in the same intercropping systems, $30 \mathrm{~kg} \mathrm{ha}^{-1} \mathrm{~N}$ combined with filtered air also gave the second highest output of protein (1.05 $\left.\mathrm{t} \mathrm{ha}^{-1}\right)$, which was nonsignificantly $(\mathrm{P}>0.05)$ different from the highest value. On the other hand, filtered air always showed higher protein than unfiltered air, and $120 \mathrm{~kg} \mathrm{~N} \mathrm{ha}^{-1}$ had the lowest value compared to the remaining $\mathrm{N}$ dosages.

\section{Discussion}

Globally, sweet sorghum is grown for multiple purposes such as a food, feed, and fiber [35]. It can tolerate adverse conditions such as water [11, 12], nutrients [36] and other stresses [37]. Due to inherent abilities, sweet sorghum is preferred to many other crops in stress-prone ecosystems [38]. Being a cereal with slow initial growth, there is an enormous potential for enhancing food production of land devoted to sweet sorghum with intercropping using early maturing crops like legumes [39]. This study explored the potential of intercropping with legumes - especially soybean and mungbean due to their importance as food and industrial crops, and hence nitrogen and air quality management were examined in the current study. Modifications of agronomic practices were considered to promote crop yields per unit of land area.

Average growth and yield parameters including LAI, plant height and grain yield in sweet sorghum were significantly reduced when intercropped compared to its sole crop, and the reductions recorded were 10.3, 
Table 2. Land equivalent ratio (LER) of sweet sorghum + mungbean and sweet sorghum + soybean intercropping systems.

\begin{tabular}{|c|c|c|c|c|c|}
\hline Treatment & $\begin{array}{l}\text { Sweet sorghum } \\
\text { grain yield, } \mathrm{t} \mathrm{ha}^{-1}\end{array}$ & $\begin{array}{c}\text { Mungbean } \\
\text { seed yield, } t \text { ha }^{-1}\end{array}$ & LER & $\begin{array}{c}\text { Soybean } \\
\text { seed yield, } \mathrm{t} \mathrm{ha}^{-1}\end{array}$ & LER \\
\hline Sole crop & $5.1 \pm 0.4$ & $2.3 \pm 0.5$ & 1.0 & $2.3 \pm 0.2$ & 1.0 \\
\hline \multicolumn{6}{|l|}{ Intercropping } \\
\hline \multicolumn{6}{|l|}{ Type of intercrop } \\
\hline Mungbean + Sweet sorghum & $4.5 \pm 0.1^{\mathrm{b} 1 /}$ & $1.9 \pm 0.2$ & 1.8 & - & - \\
\hline Soybean + Sweet sorghum & $5.2 \pm 0.1^{\mathrm{a}}$ & $-2 /$ & - & $1.5 \pm 0.2$ & 1.7 \\
\hline $\operatorname{LSD}(\mathrm{P}=0.05)$ & 0.1 & - & - & & \\
\hline \multicolumn{6}{|c|}{$\mathrm{N}$ dose, $\mathrm{kg} \mathrm{ha}^{-1}$} \\
\hline 30 & $4.5 \pm 0.1^{\mathrm{a}}$ & $2.1 \pm 0.1^{\mathrm{a}}$ & 1.8 & $1.8 \pm 0.2^{\mathrm{b}}$ & 1.7 \\
\hline 60 & $5.0 \pm 0.2^{\mathrm{c}}$ & $2.1 \pm 0.2^{\mathrm{a}}$ & 1.9 & $1.9 \pm 0.3^{\mathrm{a}}$ & 1.8 \\
\hline 120 & $5.1 \pm 0.1^{\mathrm{b}}$ & $1.6 \pm 0.2^{\mathrm{b}}$ & 1.7 & $0.8 \pm 0.1^{\mathrm{c}}$ & 1.4 \\
\hline $\operatorname{LSD}(\mathrm{P}=0.05)$ & 0.1 & 0.2 & - & 0.3 & - \\
\hline \multicolumn{6}{|c|}{ Type of air } \\
\hline Filtered & $4.9 \pm 0.1^{\mathrm{a}}$ & $2.1 \pm 0.1^{\mathrm{a}}$ & 1.9 & $1.8 \pm 0.3^{\mathrm{a}}$ & 1.8 \\
\hline Ambient & $4.8 \pm 0.1^{\mathrm{b}}$ & $1.7 \pm 0.2^{\mathrm{b}}$ & 1.7 & $1.2 \pm 0.1^{\mathrm{b}}$ & 1.5 \\
\hline $\operatorname{LSD}(\mathrm{P}=0.05)$ & 0.1 & 0.2 & - & 0.3 & - \\
\hline
\end{tabular}

1/ different alphabets on means of same parameter indicates significant difference due to treatment and vice versa.

$2 /$ - indicates not applicable

10.7, 13.5 , and $10.5 \%$, respectively, when intercropped with mungbean compared to sole crop. Only LAI of sweet sorghum was insignificantly reduced by 2.1 when associated with soybean. On the other hand, average plant height and grain yield of sweet sorghum was increased by 3.4 and $2.5 \%$, respectively, when intercropped with soybean compared to sole crop. These yield reductions would be primarily attributed to competition between sweet sorghum and legume in intercropping for growth resources as also reported by others [40]. Results showed that soybean as intercrop did not exert a greater pressure on sweet sorghum instead of having some mutual cooperation, as compared to mungbean.

Mungbean has a faster growth habit and greater competitive ability than soybean [41]. Doubled plant population of mungbean and lower intra-row spacing between sweet sorghum and mungbean have aggravated the competitive ability between sweet sorghum and mungbeanand thus led to a reduction of growth and yield parameters. Sweet sorghum would have been non-competitive and cooperative with soybean as it hasa greater ability to fix atmospheric nitrogen (range of $56-89 \%$ of total plant $\mathrm{N}$ ) compared to mungbean (45-76\% of total plant $\mathrm{N}$ ) and being able to make available a part of such $\mathrm{N}$ to associated plants [42]. The LAI, plant height and grain yield of intercropped sweet sorghum were significantly decreased by $10.5,8.4$, and $8.5 \%$, respectively, when $\mathrm{N}$ dose was reduced to $30 \mathrm{~kg}$ $\mathrm{ha}^{-1}$ compared to $60 \mathrm{~kg} \mathrm{ha}^{-1}$. These reductions showed that intercrop competition occurred for $\mathrm{N}$ instead of supplementation of $\mathrm{N}$ by the associated legume. Abd El-Lattief [43] and Ajeigbe et al. [44] observed that increasing $\mathrm{N}$ levels increased grain yield of sorghum.

The purpose of growing legumes with sweet sorghum was to gain additional yields, in addition to sweet sorghum to improve quantity and quality of food due to likely addition of protein from legume, and also to promote resource utilization by legumes during the early growth period of sweet sorghum before commencing its high resource-demanding period. The addition of yield by intercropped legume to production of cultivated lands would give yield advantages [45]. Average LAI, plant height and seed yield in mungbean were reduced by $23.7,30.0$, and $18 \%$, respectively, when intercropped with sweet sorghum compared to its sole crop due to competition. Average LAI of soybean was increased by $11.3 \%$ compared to sole crop, but both plant height and seed yield were reduced by $33 \%$, in intercropping compared to sole crop. The reduction in legume yield could partly be attributed to shading and competition for soil nutrition, which resulted from the dominance effect of plant height and high leaf area (shading), and thealellopathic effect of associated sweet sorghum [46]. According to the source-sink relationship, an increase in grain size in sole crop of soybean during pod development and seed filling period due to proximity of source (pod wall) and sink (seed) was reported [47]. When soybean intercropped, this ability appeared to be hindered due to shading by sweet 
Table 3. Effect of type of intercropping, $\mathrm{N}$ dose and air quality on carbohydrate, protein, fat and energy yields in intercropping systems.

\begin{tabular}{|c|c|c|c|c|}
\hline Treatment & Carbohydrate, $\mathrm{t} \mathrm{ha}^{-1}$ & Protein, $\mathrm{t} \mathrm{ha}^{-1}$ & Fat, $\mathrm{t} \mathrm{ha}^{-1}$ & Energy, MJha $^{-1}$ \\
\hline Sole crop sweet sorghum & $3.58 \pm 0.27$ & $0.53 \pm 0.04$ & $0.16 \pm 0.02$ & $74.61 \pm 5.64$ \\
\hline \multicolumn{5}{|l|}{ Intercropping } \\
\hline \multicolumn{5}{|l|}{ Type of intercropping } \\
\hline Mungbean + Sweet sorghum & $4.39 \pm 0.17^{\mathrm{b} 1 /}$ & $0.93 \pm 0.05^{\mathrm{a}}$ & $0.16 \pm 0.01^{\mathrm{b}}$ & $95.02 \pm 3.87^{b}$ \\
\hline Soybean + Sweet sorghum & $4.61 \pm 0.21^{\mathrm{a}}$ & $0.90 \pm 0.06^{\mathrm{a}}$ & $0.18 \pm 0.01^{\mathrm{a}}$ & $98.98 \pm 4.77^{\mathrm{a}}$ \\
\hline $\operatorname{LSD}(\mathrm{P}=0.05)$ & 0.145 & NS & 0.004 & 3.287 \\
\hline \multicolumn{5}{|c|}{$\mathrm{N}$ dose, $\mathrm{kg} \mathrm{ha}^{-1}$} \\
\hline 30 & $4.42 \pm 0.16^{\mathrm{b}}$ & $0.94 \pm 0.05^{\mathrm{b}}$ & $0.16 \pm 0.01^{\mathrm{c}}$ & $95.81 \pm 3.69^{\mathrm{b}}$ \\
\hline 60 & $4.74 \pm 0.28^{\mathrm{a}}$ & $0.99 \pm 0.08^{\mathrm{a}}$ & $0.18 \pm 0.01^{\mathrm{a}}$ & $102.47 \pm 6.24^{\mathrm{a}}$ \\
\hline 120 & $4.34 \pm 0.14^{\mathrm{c}}$ & $0.82 \pm 0.04^{\mathrm{c}}$ & $0.17 \pm 0.01^{\mathrm{b}}$ & $92.73 \pm 3.03^{\mathrm{b}}$ \\
\hline $\operatorname{LSD}(\mathrm{P}=0.05)$ & 0.178 & 0.052 & 0.005 & 4.025 \\
\hline \multicolumn{5}{|c|}{ Type of air quality } \\
\hline Filtered & $4.67 \pm 0.19^{\mathrm{a}}$ & $0.97 \pm 0.06^{\mathrm{a}}$ & $0.17 \pm 0.01^{\mathrm{a}}$ & $101.04 \pm 4.35^{\mathrm{a}}$ \\
\hline Ambient & $4.33 \pm 0.19^{\mathrm{b}}$ & $0.85 \pm 0.05^{\mathrm{b}}$ & $0.17 \pm 0.01^{\mathrm{a}}$ & $92.97 \pm 4.29^{b}$ \\
\hline $\operatorname{LSD}(\mathrm{P}=0.05)$ & 0.145 & 0.043 & 0.004 & 3.287 \\
\hline $\mathrm{CV}, \%$ & 4.7 & 6.8 & Ns & 4.9 \\
\hline
\end{tabular}

$1 /$ different alphabets on means of same parameter indicates significant difference and vice versa

sorghum, thus reducing opportunities for maintaining same-seed yield as in the sole crop.

Individual factors as well as the interactions between $\mathrm{N}$ dose and air quality on LAI, plant height, and seed yield of intercropped mungbean and soybean were significant. The $\mathrm{N}$ dose of $20 \mathrm{~kg} \mathrm{ha}^{-1}$ and filtered air produced LAI, plant height and seed yield almost on par with each variable of the sole crop. Growth and yield parameters in intercropped legumes gradually decreased as the level of $\mathrm{N}$ increased, because gradual increases in shading with increased growth of dominant sweet sorghum with the availability of mineral $\mathrm{N}$ resulted from $\mathrm{N}$ release. At lower $\mathrm{N}$ dose, the growth of sweet sorghum was reduced, which in turn reduced shading on adjacent legumes, and as a result legume had the opportunity to increase its photosynthesis and dry matter and seed yield. Reduction in growth and yield parameters of intercrop legume was also observed by Abate and Alemayehu [48]. Under ambient air, LAI, plant height and seed yield were significantly reduced in intercropped mungbean by $28.0,29.0$, and $20.5 \%$, and in intercropped soybean by $13.9,29.0$, and $16.0 \%$, respectively, compared to the same variables under filtered air, which showed reductions in $\mathrm{O}_{3}, \mathrm{NO}_{2}$ and $\mathrm{SO}_{2}$ below threshold levels of sensitivity, and hence plants in filtered air treatment were free from adverse and hidden interferences. In ambient air of the experimental area, concentrations of ozone at $2,4,6,8,10$, and 12 weeks after seeding were 57.4, 62.6, 55.4, 49.8, 52.7, and $44.9 \mathrm{ppb}$, respectively; that of nitrogen dioxides were
48.4, 49.5, 47.4, 45.8, 45.2, and $40.7 \mathrm{ppb}$, respectively; and for sulfur dioxide were 18.8, 17.6, 11.7, 10.5, 12.0, and $14.9 \mathrm{ppb}$, respectively. As per reports published, an ozone level of $40 \mathrm{ppb}$ was the threshold level for dicots, and legume being dicots, higher ozone concentration in air may have had a negative effect on growth and yield of legumes as also reported by Zhang et al. [49]. Reduction in growth and yield parameters of mungbean due to combined influence of air pollutants $\left(\mathrm{O}_{3}, \mathrm{NO}_{2}, \mathrm{SO}_{2}\right)$ were also observed by Chaudhary and Agrawal [50]. This indicates and alarms the future threat of increasing air pollution on legume-based food production and food security.

Land equivalent ratio (LER) decreased by $10.3 \%$ in sweet sorghum-mungbean intercropping compared to sweet sorghum-soybean intercropping. It was decreased significantly by $10.5 \%$ in sweet sorghum-mungbean and $22 \%$ in sweet sorghum-soybean associations due to decreased $\mathrm{N}$ at $120 \mathrm{~kg} \mathrm{ha}^{-1}$ compared to $60 \mathrm{~kg} \mathrm{ha}^{-1}$. Nitrogen dose of $60 \mathrm{~kg} \mathrm{ha}^{-1}$ gave highest LER that was on par with the $\mathrm{N}$ dose of $30 \mathrm{~kg}$. This could be due to enhanced performance of sweet sorghum at 60 and $120 \mathrm{~kg} \mathrm{ha}^{-1}$ and lower performance of legume at $120 \mathrm{~kg} \mathrm{ha}^{-1}$ of $\mathrm{N}$. Several researchers have reported inferior performance of legumes at high $\mathrm{N}$ rates due to declining biological $\mathrm{N}$ fixation, on which plant $\mathrm{N}$ requirement is mainly dependent [51]. On the other hand, cereals show lower performance at low soil $\mathrm{N}$ levels and vice versa [43]. Withdrawal of soil $\mathrm{N}$ is known to facilitate and promote BNF of legumes [52]. 
However, when both legume and cereal are planted in closer rows and apply with higher doses of $\mathrm{N}$, such $\mathrm{N}$ would impair and hinder the nodule activity of the legume. This impairment may affect BNF of root nodules, and under such conditions, the legume will have to be dependent upon fertilizer N. This situation appeared to have occurred with the application of $\mathrm{N}$ as top dressing to sweet sorghum at 30 days after seeding. Therefore, enhanced performance of sweet sorghum and reduced performance of legume at higher $\mathrm{N}$ rates and vice versa were explicitly seen. The $60 \mathrm{~kg} \mathrm{ha}^{-1}$ of $\mathrm{N}$ made a compromise, thus improving crop yield as expressed with LER of 1.8-1.9 with mungbean and soybean, respectively. The result also showed that yield of legumes was more contributory to LER than sweet sorghum in the current study. The results are in congruity with the findings of Sibhatu et al. [53], where the increasing level of $\mathrm{N}$ increased the LER in maizePhaseolus beans intercropping.

Filtered air enhanced the production of both sweet sorghum and legumes, and thus increased the LER value by $12 \%$ compared to ambient air. Average total yield of carbohydrates, proteins, fats, and energy was increased by $18.5,43.0,0.0$, and $21.5 \%$ in sweet sorghum-mungbean intercropping and by $22.3,41.0$, 11.0 , and $24.6 \%$, respectively, in sweet sorghum-soybean intercropping compared to sole crop of sweet sorghum. The interaction among intercropped soybean, $\mathrm{N}$ dose of 30 or $60 \mathrm{~kg} \mathrm{ha}^{-1}$ and filtered air resulted in the highest protein yield in sweet sorghum-soybean association.

\section{Conclusions}

The current study showed that growing sweet sorghum with legumes (soybean or mungbean) in intercropping was more beneficial than sole cropping. In intercropping sweet sorghum with soybean or mungbean, $\mathrm{N}$ management and air quality appeared to be of utmost importance in order to reduce competition for the main crop or for both. Intercropping using $60 \mathrm{~kg} \mathrm{ha} \mathrm{h}^{-1}$ of $\mathrm{N}$ proved superior to both 30 and $120 \mathrm{~kg} \mathrm{ha}^{-1}$ because of optimized and compromised performance of sweet sorghum and legume. Similarly, filtered air increased the productivity of intercropping. Therefore, intercropping sweet sorghum with mungbean or soybean provided with $\mathrm{N}$ dose of $60 \mathrm{~kg} \mathrm{ha}^{-1}$ and filtered air resulted in reduced competition and enhanced land productivity for grain and seed yields and associated food ingredients and digestible energy production.

\section{Acknowledgments}

The corresponding author acknowledges the financial assistance provided by the Higher Education Commission (HEC) of Pakistan in the form of scholarship for MS leading to a PhD program, and facilitation provided by Agriculture Systems and Engineering field of study, Asian Institute of Technology, Pathumthani, Thailand, for conducting PhD research work at the research farm.

\section{Conflict of Interest}

The authors declare that they have no conflict of interest.

\section{References}

1. LICHTFOUSE E. Climate Change, Intercropping, Pest Control and Beneficial Microorganisms. Springer Dordrecht Heidelberg London New York, 2009.

2. KOOCHEKI A., MAHALLATI M.N., SOLOUKI H., KARBOR S. Evaluation of Radiation Absorption and use Efficiency in Substitution Intercropping of Sesame (Sesamum Indicum L.) and Mung Bean (Vigna Radiata L.). Adv Plants Agric Res., 3, 00109, 2016.

3. RAHMAN T, LIU X, HUSSAIN S, AHMED S, CHEN G, YANG F. Water use efficiency and evapotranspiration in maize-soybean relay strip intercrop systems as affected by planting geometries. PLoS ONE, 12, e0178332, 2017.

4. GAO Y, WU P, ZHAO X, WANG Z. Growth, yield, and nitrogen use in the wheat/maize intercropping system in an arid region of northwestern China. Field Crops Res., 167, 19, 2014

5. KNORZER H., GRAEFF-HONNINGER S., GUO B., WANG P., CLAUPEIN W. The Rediscovery of Intercropping in China: A Traditional Cropping System for Future Chinese Agriculture - A Review. In: E. Lichtfouse (ed.), Climate Change, Intercropping, Pest Control and Beneficial 13 Microorganisms, Sustainable Agriculture Reviews 2. Springer Science + Business Media B.V. 2009.

6. KERMAH M.,FRANKE A.C.,ADJEI-NSIAH S., AHIABOR B.D.K., ABAIDOO R.C., GILLER K.E. Maize-grain legume intercropping for enhanced resource use efficiency and crop productivity in the Guinea savanna of northern Ghana. Field Crops Research, 213, 38, 2017.

7. MALOBANE M.E., NCIIZAH A.D., WAKINDIKI I.I.C., MUDAU F.N. Sustainable production of sweet sorghum for biofuel production through conservation agriculture in South Africa. Food Energy Secur. 7, e00129, 2018.

8. MENGISTU M., STEYN J., KUNZ R., DOIDGE I., HLOPHE H., EVERSON C., CLULOW A. A preliminary investigation of the water use efficiency of sweet sorghum for biofuel in South Africa. Water SA, 42, 152, 2016.

9. KRISHNAMURTHY L., DINAKARAN E., KUMAR A.A., REDDY B.V.S. Field Technique and Traits to Assess Reproductive Stage Cold Tolerance in Sorghum (Sorghum bicolor (L.) Moench, Plant Production Science, 17, 218, 2014.

10. FU T., KO J., WALL G.W., PAUL J. PINTER P.J., JR., KIMBALL B.A., OTTMAN M.J., KIM H. Simulation of climate change impacts on grain sorghum production grown under free air $\mathrm{CO}_{2}$ enrichment. Int. Agrophys, 30, 311, 2016.

11. NAHAR K. Sweet Sorghum: An Alternative Feedstock for Bioethanol. Iranica J of Energy \& Environment, 2, 58, 2011. 
12. VASILAKOGLOU I., DHIMA K., KARAGIANNIDIS N., GATSIS T. Sweet sorghum productivity for biofuels under increased soil salinity and reduced irrigation. Field Crops Res., 120, 38, 2011.

13. MSONGALELI B., RWEHUMBIZA F., TUMBO S.D., KIHUPI N. Sorghum Yield Response to Changing Climatic Conditions in Semi-Arid Central Tanzania: Evaluating Crop Simulation Model Applicability. Agricultural Sciences, 5, 822, 2014.

14. MOLAALDOILA Y., AL-MOSANIF E., Al-AQIL M., Al-KUMALI A. Effect of Nitrogen Levels on Yield, Competitive, Economic indices and Efficiency of Sorghum cultivars and Common Bean Intercropping. Agri Res \& Tech: Open Access J.,3, 555614, 2017.

15. TAIA W., JALAL BASAHI J., HASSAN I. Impact of Ambient Air on Physiology, Pollen Tube Growth, Pollen Germination and Yield in Pepper (Capsicum Annuum L.). Pak. J. Bot.,45, 921, 2013.

16. SINGH J.S., SINGH S.P., GUPTA S.R. Ecology Environmental Science \& Conservation S. Chand \& Company Pvt Ltd, 2015.

17. MAMAN N., TRAORÉ L., GARBA M., DICKO M.K. GONDA A., WORTMANN C.S. Maize sole crop and intercrop response to fertilizer in Mali and Niger. Agron. J., 110, 728, 2018.

18. RAHMAN K.M.A., ZHANG D. Effects of Fertilizer Broadcasting on the Excessive Use of Inorganic Fertilizers and Environmental Sustainability. Sustainability, 10, 759, 2018.

19. TAI A.P.K., MARTIN M.V. Impacts of ozone air pollution and temperature extremes on crop yields: Spatial variability, adaptation and implications for future food security. Atmospheric Environment, 169, 11-21, 2017.

20. NILAHYANE A., ISLAM M.A., MESBAH A.O., GARCIA A.G. Effect of Irrigation and Nitrogen Fertilization Strategies on Silage Corn Grown in SemiArid Conditions. Agronomy, 8, 208, 2018.

21. BECKMAN J., BORCHERS A., JONES C.A. Agriculture's Supply and Demand for Energy and Energy Products. Economic Information Bulletin Number 112. United States Department of Agriculture, 2013.

22. SALLY W., GINA M., ROSEMARY I., WILLIAM D.J. How is ozone pollution reducing our food supply? Journal of Experimental Botany, 63, 527, 2012.

23. BACIAK M., WARMIŃSKI K., BES A. The effect of selected gaseous air pollutants on woody plants. Leśne Prace Badawcze, 76, 401, 2015.

24. HARMENS H., MILLS G., HAYES F., NORRIS D. Air Pollution and Vegetation ICP Vegetation. Annual Report 2010/2011. ICP Vegetation Programme Coordination Centre, Centre for Ecology and Hydrology, Environment Centre Wales, Deiniol Road, Bangor, Gwynedd, LL57 2UW, UK, 2011.

25. MICHEL A., SEIDLING W. Forest Condition in Europe: 2015 Technical Report of ICP Forests. Report under the UNECE Convention on Long-Range Transboundary Air Pollution (CLRTAP). Vienna: BFW Austrian Research Centre for Forests. BFW Dokumentation 21/2015. 182 p, 2015.

26. EPA (Environment Protection Authority). Emission Testing Methodology for Air Pollution. Version 2. Environment Protection Authority GPO Box 2607 Adelaide SA 5001, 2012.

27. WEISS M., BARET F., SMITH G., JONCKHEERE I., COPPIN P. Review of methods for in situ leaf area index
(LAI) determination. Agricultural and Forest Meteorology, 121, 37, 2004

28. GARNIER E., SHIPLEY B., ROUMET C., LAURENT G. A standardized protocol for the determination of specific leaf area and leaf dry matter content. Functional Ecology, 15, 688, 2001.

29. MORALES-ROSALES E.A., FRANCO-MORA O. Biomass, yield and land equivalent ratio of Helianthus annus L. In sole crop and intercropped with Phaseolus vulgaris L. in high valleys of Mexico Tropical and Subtropical Agroecosystems, 10, 431, 2009.

30. USDA. Nutrient Data Laboratory USDA. National Nutrient Database for Standard, 2011. Reference. http://www.nal. usda.gov/fnic/foodcomp/search/ (Retrieved on December 2011).

31. WHO (World Health Organization)/. Guideline: sugars intake for adults and children. WHO Library Cataloguing-in-Publication Data. WHO Press, World Health Organization, 20 Avenue Appia, 1211 Geneva 27, Switzerland. 2015

32. ABDI H., WILLIAMS L.J. Contrast Analysis. In Neil Salkind (Ed.), Encyclopedia of Research Design. Thousand Oaks, CA, 2010.

33. SELTMAN H.J. Two-way ANOVA in Experimental Design and Analysis, Chapter 11, 2009. Available online at: http://www.stat.cmu.edu/_hseltman/309/Book/Book. pdf

34. SULTANA S., IQBAL M.M., AKHTAR M. A Visualization of Fisher's Least Significant Difference Test. Pakistan Journal of Commerce and Social Sciences. 7 (1), 100,2013

35. MAZUMDAR S.D., POSHADRI A., RAO P.S., REDDY C.H.R., REDDY B.V.S. Innovative use of Sweet sorghum juice in the beverage industry. International Food Research Journal, 19, 1361, 2012.

36. HAN L.P., STEINBERGER Y., ZHAO Y.L., XIE G.H. Accumulation and partitioning of nitrogen, phosphorus and potassium in different varieties of sweet sorghum. Field Crops Res., 120, 230, 2011.

37. TARI I., LASKAY G., TAKACS Z., PO P. Responses of Sorghum to Abiotic Stresses: A Review. J Agro. Crop Sci.,2012. doi: 10.1111/jac.12017

38. ANAMI S.E., ZHANG L.M., XIA Y., ZHANG Y.M., LIU Z.Q., JING H.C. Sweet sorghum ideotypes: genetic improvement of the biofuel syndrome. Food Energy Secur. 4, 159, 2015.

39. ARSHAD M., RANAMUKHAARACHCHI S.L. Effects of Legume Type, Planting Pattern and Time of Establishment on Growth and Yield of Sweet SorghumLegume Intercropping. Australian Journal of Crop Science, 6, 1265, 2012.

40. EKHLAS M. MUSA, ELSIDDIG A. E. ELSHEIKH, ISAM A. MOHAMED AHMED, ELFADIL E. BABIKER. "Intercropping Sorghum (Sorghum bicolor L.) and Cowpea (Vigna unguiculata L.): Effect of Bradyrhizobium Inoculation and Fertilization on Minerals Composition of Sorghum Seeds," ISRN Agronomy, 2012, 9. Article ID 356183, 2012.

41. WORKU W. Sequential Intercropping of Common Bean and Mung Bean with Maize in Southern Ethiopia, 50, 90, 2014.

42. HAMAWAKI R.L., KANTARTZ S.K. Di-nitrogen fixation at the early and late growth stages of soybean. ActaScientiarum Agronomy, 40, e36372, 2018.

43. ABD EL-LATTIEF E.A. Nitrogen Management Effect on the Production of Two Sweet Sorghum Cultivars under 
Arid Regions Conditions. Asian Journal of Crop Science, 3, 77, 2011.

44. AJEIGBE H.A., AKINSEYE F.M., AYUBA K., JONAH J. Productivity and Water Use Efficiency of Sorghum (Sorghum bicolor (L.) Moench) Grown under Different Nitrogen Applications in Sudan Savanna Zone, Nigeria. International Journal of Agronomy, 2018, 11, 2018.

45. KERMAHA M., FRANKEB A.C., ADJEI-NSIAHC S., AHIABORD B.D.K., ABAIDOOC R.C., GILLERA K.E. Maize-grain legume intercropping for enhanced resource use efficiency and crop productivity in the Guinea savanna of northern Ghana. Field Crops Research, 213, 38, 2017.

46. MOOSAVI A., REZA T.A., ABOUZAR A., MOHAMMAD H.G. Allelopathic effects of Aqueous extract of leaf stem and root of sorghum bicolor on seed, germination and seedling growth of Vigna radiata (L). Not. Sci. Biol., 3, 114, 2011.

47. SILVA A.J., FILHO J.R.M., SALES C.R.G., PIRES R.C.M., MACHADO E.C. Source-sink relationships in two soybean cultivars with indeterminate growth under water deficit. Bragantia, Campinas, 77, 23, 2018.

48. ABATE M., ALEMAYEHU G. Biological Benefits of Intercropping Maize (Zea mays L) with Fenugreek, Field Pea and Haricot Bean Under Irrigation in Fogera Plain,
South Gonder Zone, Ethiopia. Agriculture, Forestry and Fisheries, 7, 19, 2018.

49. ZHANG W., WANG G., LIU X., FENG Z. Effects of elevated $\mathrm{O} 3$ exposure on seed yield, $\mathrm{N}$ concentration and photosynthesis of nine soybean cultivars (Glycine max (L.) Merr.) in Northeast China. Plant Science, 226, 172, 2014.

50. CHAUDHARY N., AGRAWA S.B. The role of elevated ozone on growth, yield and seed quality amongst six cultivars of mung bean. Ecotoxicology and Environmental Safety, 111, 286, 2015.

51. PAMPANA, S., MASONI, A., MARIOTTI, M., ERCOLI, L., ARDUINI, I. Nitrogen Fixation of Grain Legumes differs in Response to Nitrogen Fertilization. Experimental Agriculture, 54, 66, 2018.

52. HANNAWAY D.B., WANG D., QIN Y., GAMAL, FADUL G.M.A. Effect of nitrogen fertilization on yield, $\mathrm{N}$ content, and nitrogen fixation of alfalfa and smooth bromegrass grown alone or in mixture in greenhouse pots. Journal of integrative agriculture, 14, 1864, 2015.

53. SIBHATU B., BELETE K., TESSEMA T. Effect of Cowpea Density and Nitrogen Fertilizer on a SorghumCowpea Intercropping System in Kobo, Northern Ethiopia, International Journal of Agriculture and Forestry, 5, 305, 2015. 